\title{
Karakteristik patty burger yang dibuat dari daging itik dengan berbagai persentase tepung talas
}

\section{Characteristics of burger patties made from duck meat with various percentages of taro flour}

\author{
Daniyal Hanafi ${ }^{1}{ }^{1}{ }^{*}$ Deni Novia ${ }^{1)}$, and Aronal Arief Putra ${ }^{1)}$ \\ ${ }^{1)}$ Division of Technology of Animal Products, Faculty of Animal Science, Universitas Andalas, \\ Kampus Limau Manis, Padang, 25163, West Sumatra, Indonesia \\ *dnovia@ansci.unand.ac.id
}

\begin{abstract}
Diterima : 05 Januari 2020
Disetujui : 29 Februari 2020

Diterbitkan : 29 Februari 2020
\end{abstract}

\begin{abstract}
Abstrak: $\quad$ Penggunaan tepung talas sebagai bahan pengikat pada pembuatan patty burger yang dibuat dari daging itik telah dilakukan. Persentase tepung talas berbeda (o, 5, 10, dan 15\%) digunakan sebagai perlakuan. Patty yang dihasilkan dianalisis untuk sifat fisik (kadar air, susut masak, penyusutan diameter, peningkatan ketebalan, tekstur) dan profil sensori (warna, aroma, rasa, tekstur, dan daya terima keseluruhan). Kadar air, susut masak, dan penyusutan diameter dari sampel menurun secara signifikan dengan peningkatan penggunaan tepung talas, tetapi peningkatan ketebalannya meningkat $(P<0.05)$. Warna, rasa, dan penerimaan keseluruhan juga meningkat dengan persentase penggunaan tepung talas yang semakin besar. Sebagai kesimpulan, penggunaan 10 persen tepung talas pada formulasi menjadi perlakuan terbaik dalam pembuatan daging burger.
\end{abstract}

Kata Kunci: bahan pengikat, patty burger, tepung bebas gluten, talas

Abstract: The utilization of taro flour as binder in burger patties made from duck meat already conducted. Different taro percentages (o, 5, 10, and 15\%) were used as treatment. Physical properties (moisture, cook loss, diameter reduction, thickness accretion, texture) and sensory profiles (color, aroma, taste, texture, and overall acceptances) of produced patties were analyzed. Moisture, cook loss, and diameter reduction of sample were significantly decreased by increasing taro flour percentage, but thickness accretion was enhanced $(P<0.05)$. Color, taste, and overall acceptances were also increased with higher percentage of taro flour used $(P<0.05)$. In summary, 10 percent of taro flour incorporation in the formulation was considered as the best percentage in patties manufacturing.

Keywords: binder, burger patties, free-gluten flour, taro.

\section{Introduction}

Burger is a processed food consists of cooked meat patties with vegetables, sauces, and mayonnaise flanked by two sliced breads, while cheese slice as a common optional component could also be added [1]. Lettuce and onion are two frequent vegetables used, while tomato, chili, and black pepper sauces could be applied alone or combined. Meat from chicken and cattle are the most common meat used for commercial patties in the market. Nevertheless, some other meat sources could also be alternatives such as fish or duck meat.

Duck meat might be considered as the secondary meat class among various poultry meat sources. The limitation usage of duck meat probably related to the specific flavor of meat, which is less acceptable for some people. Hence, the utilization of duck meat is mostly found in traditional food which usually natural flavoring-rich. Conversely, this becomes a challenge to enhance duck meat consumption by using such meat sources as a basis for patties. However, some previous researches already applied duck meat in formulation of sausages [1]; [2], meatballs [4], and nuggets [5].

Binder is an important component in most restructured meat products production. In fact, patties could be prepared with or without binder. Birder might be not used for making traditional fresh patties, but is mainly used for most packaged- and stored-commercial patties. In spite of its importance to reduce the cost production due to its reasonable price, the using of binder also significant to produce desired textural properties of restructured meat products. Flours commonly produce from cereals and 
tubers. Limited researches on the application of tuber flours such as tapioca flour [6]; [7], potato flour [8]; [9] already reported.

Taro (Colocasia esculenta) is categorized as a carbohydrate source from tuber and being important local commodity in Indonesia [10]. Since taro is generally not specifically aimed to be planted, this plant mostly found wildly, and not many utilized for commercial food as normally applied in cassava. Nevertheless, taro leaf occasionally used as a freshwater fish feed alternative, its petiole traditionally used as the additional component in curry, while its fresh corm sometimes processed into chips.

Nowadays, the utilization of the corm of taro in the form of flour could be found in various bakery products, while lesser applications in the other products. Since the prevalence of celiac disease enhanced consumer attention to find suitable glutenfree products [11], taro which is categorized as glutenfree tuber, could be an option. Due to its limited utilization, the application of taro as alternative flour for various products is important for future food industry.

In previous publications, $5 \%$ of taro flour already applied in chicken patties [1]. The application of a higher percentage of taro flour, however, could be considered to reduce the production cost of patties. Thus, it is interesting to view the effects of various percentages of taro flour on the physical and sensory attributes of duck patties.

\section{Materials and Method}

\subsection{Material}

The main material used during this study consists of frozen ground duck meat prepared from meat of spent duck of local breed (Kamang duck) and taro flour. Soy protein isolate, salt, konjac powder, butter, margarine, cinnamon powder, onion, garlic powder, black pepper powder, ice, and patty paper were also prepared.

\subsection{Method}

\subsubsection{Burger patty production}

Burger patty formulation was calculated as previous reference [12] with adaptation in flour percentages used. Frozen ground duck meat was combined with soy protein isolate, salt, konjac powder, butter, cinnamon powder, onion, garlic powder, black pepper powder, ice, and subsequently mixed by hand. After that, the mixture was divided into four lots and applied with taro flour as follows: (a) o\% taro flour (control) (b) 5\% taro flour (c) $10 \%$ taro flour, and (d) $15 \%$ taro flour. Percentages of flour applied were calculated based on total formulation without flour. The batter then mixed by hand again, resized and weighed into $65 \mathrm{gr}$, molded using a burger maker (HF - 100, Getra, Indonesia), and stored in the freezer for 20 hours. The raw patties were cooked with margarine as a heating medium for a total of 5 min for both sides.

\subsubsection{Laboratory analysis}

Samples were analyzed for physicochemical characteristics i.e. moisture content [13], cook loss [14], diameter reduction [14], thickness accretion [15], and texture. Sensory properties were determined by semi trained panelists for hedonic characteristics i.e. taste, texture, color, aroma, and overall acceptances. A seven-point hedonic scale was applied for sensory acceptance tests [16].

\subsubsection{Statistical analysis}

Data obtained were statistically analyzed using the SPSS program. Compared means was subjecting by ANOVA. The significance level (0.05) was determined using Duncan.

\section{Result and discussion}

The result of the moisture content of burger patties could be seen in Figure 1. This figure represents a significant difference effect obtained among various percentages of flour used $(\mathrm{P}<0.05)$.

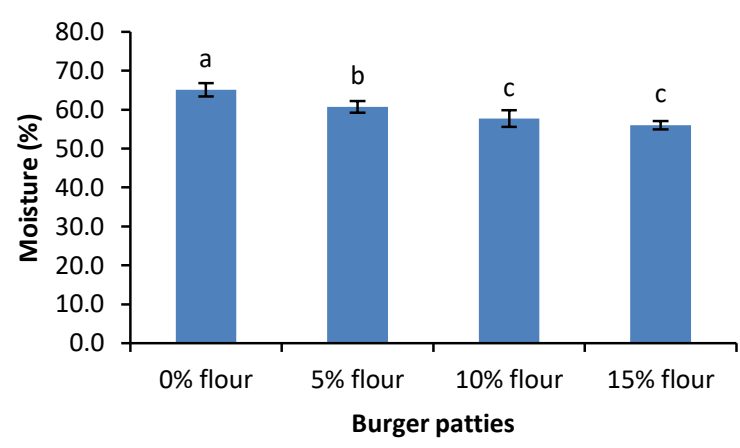

Figure 1. Moisture content of burger patties made from duck meat formulated with various percentages of taro flour $(\mathrm{n}=4)$ 

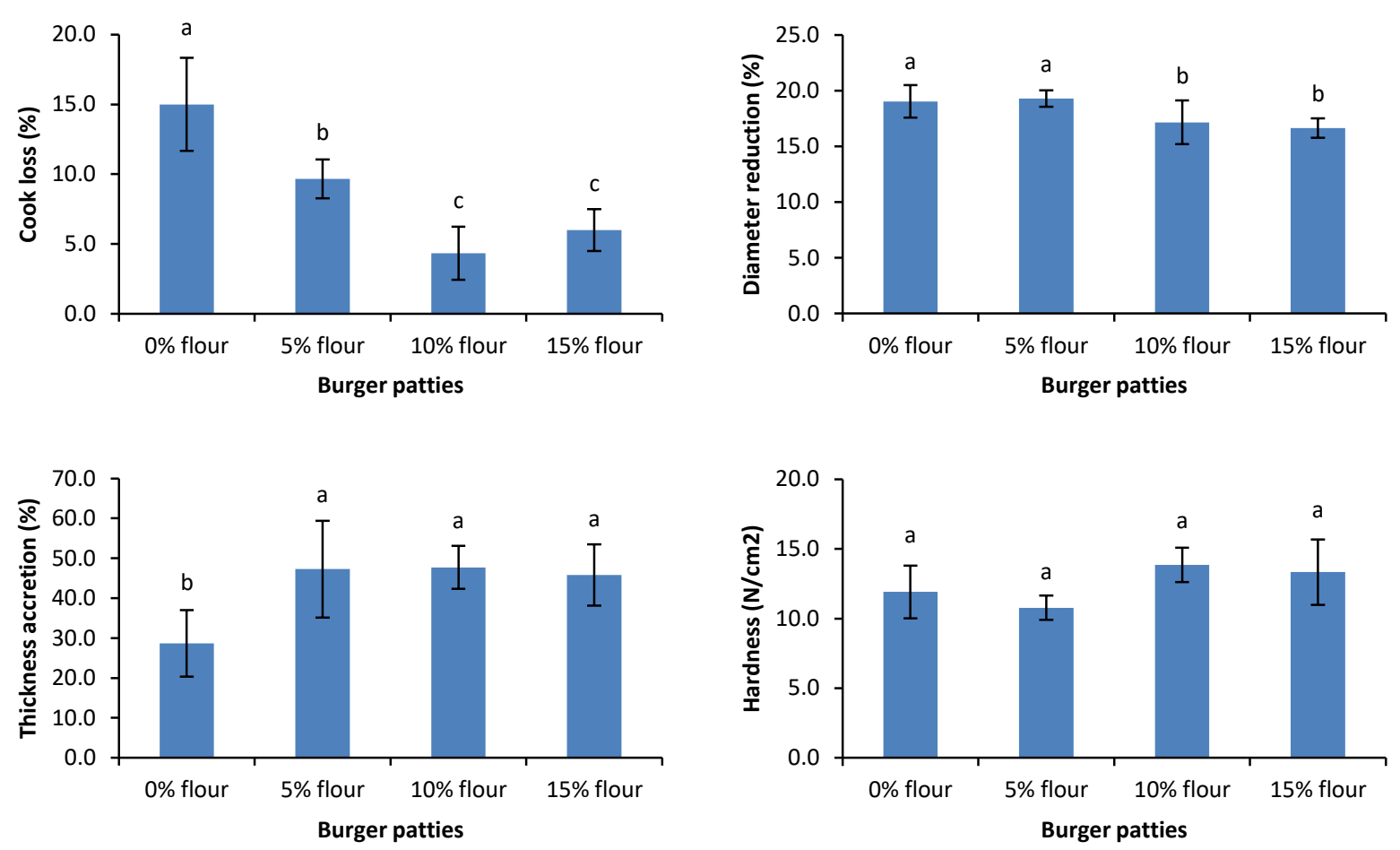

Figure 2. Cook loss, diameter reduction, thickness accretion, and texture of burger patties made from duck meat formulated with various percentages of taro flour $(n=5)$

The higher flour used, the lower moisture content of the patties. This might result due to the effect of total solid content in flour. Taro flour contains $8.19 \%$ moisture [17], 9.36\% [18]. This means that the total solid of taro starch is about $90 \%$. Such percentage caused the percentage of moisture decreased by higher addition of flour in formulation.

The results of cook loss, diameter reduction, thickness accretion, and texture of burger patties are provided in Figure 2. Cook loss and diameter reduction of the sample were significantly decreased by a higher percentage of flour used $(\mathrm{P}<0.05)$. During patties cooking, water and fat gradually released into the surface of the griddle for all samples. However, such components trapped inside the granules might not come out as easy as occurred in the sample without flour. Thus, it also caused the reduction of samples with higher flour percentage was lower than those of samples with lower flour percentages.

High content of mucilage or gum in taro [19] being an important factor in the structure of patties. Such gum characteristics create a stronger structure of the patties and thus retain more water and fat from the losses during cooking. This directly associated with lower diameter reduction in patties by higher taro flour percentage. Decreasing diameter reduction by higher percentage of flour also similar to others report that added 4,8 , and $12 \%$ of chickpea and lentil seed flour in beef patties [15]. Related to the thickness, swollen of starch granules during the dry heating process significantly create higher thickness of patties treated with taro flour compared to the control. This was associated with the explanation of [20] which noted that amylose content contributed to the swelling power of taro starch.

The result of the hedonic score on color, aroma, taste, texture, and overall acceptance of burger patties could be seen in Figure 3. Color, taste, and overall acceptances were significantly higher by increasing of taro flour used $(\mathrm{P}<0.05)$, while aroma and texture acceptances were comparable $(\mathrm{P} \geq 0.05)$. Panelists prefer the color of the sample with higher flour percentage added might be associated with lighter brown color formation, while darker brown color formation of patties with less or without taro flour was noticed. This was in concomitant with a reference which evaluated commercial patties and found that patties with yellowy color was more acceptable [21].

Moreover, the phenomenon in taste of patties were related with constituents bound by taro flour as less fat released and also specific taste formation of taro flour during patties grilling. Since significant differents on color and taste, the sensation from such attributes also resulted in significant overall acceptance by the effect of taro flour used. 

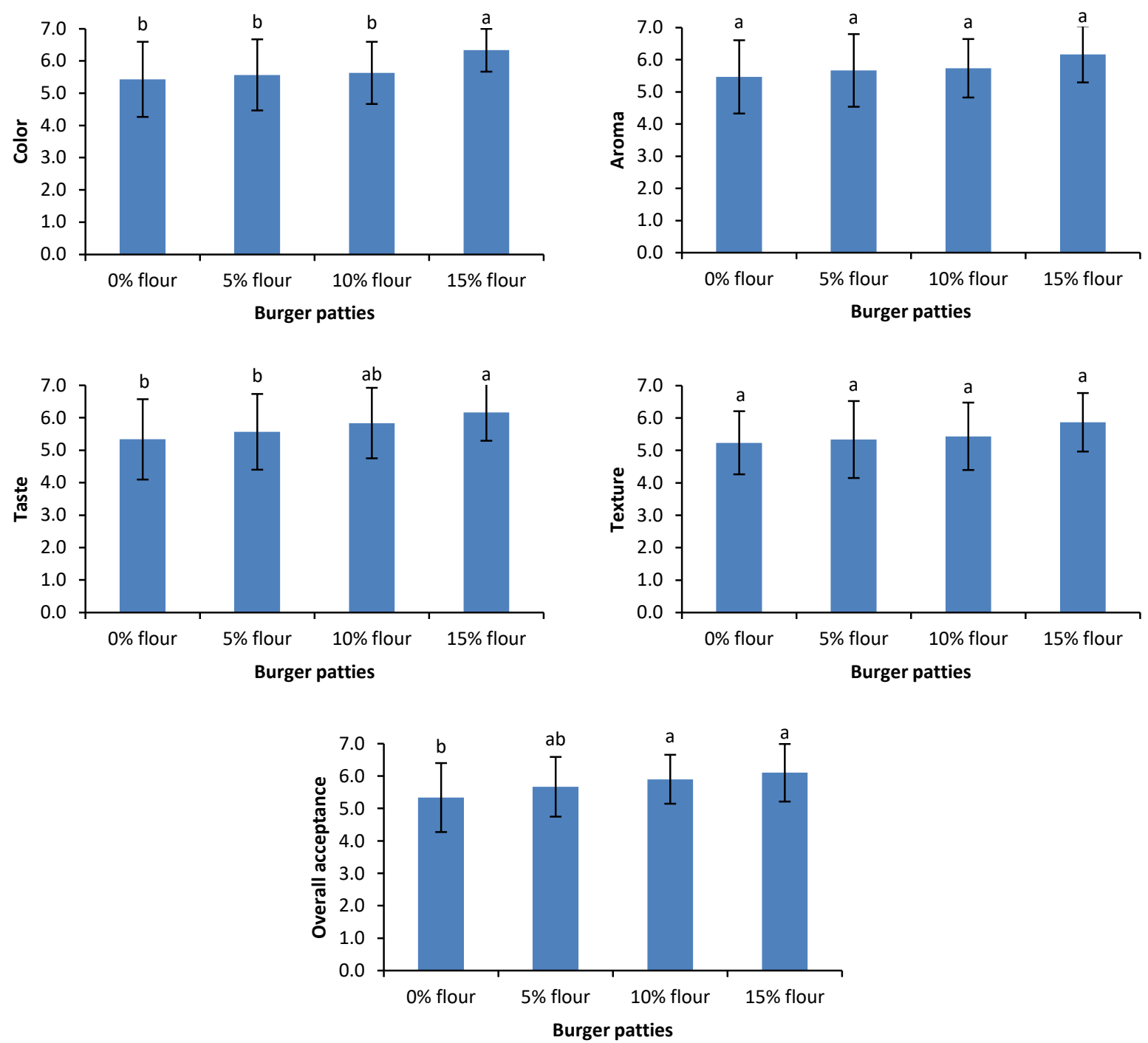

Figure 3. Color, aroma, taste, texture, and overall acceptance of burger patties made from duck meat formulated with various percentages of taro flour $(n=30)$

Eventhough no significant different obtained in texture, substantial hardening on outer side patties treated with $15 \%$ taro flour as exposed by heat during cooking was obtained. Therefore, this condition probably lead to undesirable texture sensation when the patties consumed as whole burger.

\section{Conclusion}

The using of taro flour in formulation affects moisture, cook loss, diameter reduction, thickness, and hedonic attributes of patties. The using of taro flour until $15 \%$ still exhibited positive physicochemical and hedonic attributes. Patties with $10 \%$ of taro flour might considered as best percentage added in the formulation.

\section{References}

[1] Rahmadanisa, A. A. Putra, and D. Novia. 2019. Characteristics of burger patties prepared with sorghum, taro, and breadfruit flours. Journal of Livestock and Animal Health, 2, 51-55.

[2] Muthia, D., H. Nurul, and I. Noryati. 2010. The effects of tapioca, wheat, sago and potato flours on the physicochemical and sensory properties of duck sausage. International Food Research Journal, 17, 877-884.

[3] Muthia, D., N. Huda, N. Ismail, and A. M. Easa. The effects of egg white powder addition with tapioca and sago flours on physicochemical and sensory properties of duck sausage. International Food Research Journal, 19, 14151421.

[4] Nurkhoeriyati, T., N. Huda, and R. Ahmad. 2012. Physicochemical properties and sensory analysis 
of duck meatballs containing duck meat surimilike material during frozen storage. Journal of Food Science, 71, S91-S98.

[5] Kumar, R., S. Biswas, D. Bhattacharyya, M. Ram, and V. Singh. 2014. Study on nuggets prepared from different ratios of spent duck and spent hen meat. Indian Journal of Poultry Science, 49, 228-230.

[6] Desmond, E. M., D. J. Troy, and D. J. Buckley. 1998. The effects of tapioca starch, oat fibre, and whey protein on the physical and sensory properties of low-fat beef burgers. Lebensm.Wiss. u.-Technol., 31, 653-657.

[7] Juemanee, P., K. Kijroongrojana, W. Usawakesmanee, and W. Posri. 2009. Juiciness improvement of frozen battered shrimp burger using modified tapioca starch, sodium alginate, and iota-carrageenan. Songklanakarin Journal of Science and Technology, 31, 491-500.

[8] Manaf, F. A., N. Huda-Faujan, N. Arifin, and N. B. M. Hanafiah. 2018. Physicochemical properties and consumer preference of fish burgers produced from black tilapia surimi paste and potato flour. Malaysian Journal of Health, Science, and Technology, 1, 25-35.

[9] Kilincceker, O. 2018. Effects of different starches on some of the frying and storage properties of meat patties. Advances in Food Sciences, 40, 3541.

[10] Elisabeth, D. A. A. 2015. Added value improvement of taro and sweet potato commodities by doing snack processing activity. Procedia Food Science, 3, $262-273$.

[11] Horstmann, S. W., K. M. Lynch, and E. K. Arendt. 2017. Starch Characteristics linked to gluten-free products. Foods, 6, 1-21.

[12] Ramadhan, K., N. Huda., and R. Ahmad. 2012. Physicochemical and sensory characteristics of burger made from duck surimi-like material. Poultry Science, 91, 2316-2323.

[13] AOAC. 200o. Official Metodhs of Analysis of The Association of Official Analytical Chemists. Benjamin Franklin Station, Washington DC.

[14] Dreeling, N., P. Allen, and F. Butler. 20oo. Effect of cooking method on sensory and instrumental texture attributes of low-fat beef burgers. LWTFood Science and Technology, 33, 234-238.

[15] Motamedi, A., M. Vahdani, H. Baghaei, and M. A. Borghei. 2015. Considering the physicochemical and sensorial properties of momtaze hamburgers containing lentil and chickpea seed flour. Nutrition and Food Sciences Research, 2, 55-62.

[16] Meilgaard, M., G. V. Civille, and B. T. Carr. 2016. Sensory Evaluation Techniques. 5th ed. CRC Press, Boca Raton.

[17] Aprianita, A., U. Purwandari, B. Watson, and T. Vasiljevic. 2009. Physico-chemical properties of flours and starches from selected commercial tubers available in Australia. International Food Research Journal, 16, 507-520.

[18] Indrastuti, E., M. Ramadhia, and L. Purwandani. 2014. Characteristics of kwetiau material of formulation rice flour and uwi flour, taro flour, and kimpul flour modified by heat moisture treatment (HMT). Proceeding of International Congress 2014: Challenges of Biotechnological Research in Food and Health. Pp. 41-47.

[19] Kaushal, P., V. Kumar, and H.K. Sharma. 2012. Comparative study of physicochemical, functional, antinutritional, and pasting properties of taro (Colocasia esculenta), rice (Oryza sativa) flour, pigeonpea (Cajanus cajan) flour and their blends. LWT - Food Science and Technology, 48, 59-68.

[20] Lu, T.-J., J.-H. Lin, J.-C. Chen and Y.-H. Chang. 2008. Characteristics of taro (Colocasia esculenta) starches planted in different seasons and their relations to the molecular structure of starch. Journal of Agricultural and Food Chemistry, 56, 2208-2215.

[21] Ramadhan, K., N. Huda, and R. Ahmad. 2011. Physicochemical characteristics and sensory properties of selected Malaysian commercial chicken burgers. International Food Research Journal,18, 1349-1357. 